\title{
Analisis Spasial Temporal Sosiodemografi Dan Variabilitas Iklim Terhadap Kejadian Tuberkulosis Paru BTA Positif di Provinsi Jawa Barat Tahun 2013-2017
}

\author{
Siti Fitriyani, Meliana Sari \\ Fakultas Ilmu Kesehatan, Universitas Islam Negeri Syarif Hidayatullah Jakarta \\ Email : meliana.sari@uinjkt.ac.id
}

\begin{abstract}
Abstrak
Tuberkulosis merupakan penyakit menular yang menjadi penyebab kematian tertinggi di dunia. Provinsi Jawa Barat merupakan provinsi dengan jumlah kasus TB Paru tertinggi di Indonesia. Diantara berbagai faktor yang memengaruhi kejadian TB adalah aspek keruangan. Penelitian ini merupakan studi ekologi yang bertujuan mengetahui hubungan dan autokorelasi spasial kejadian TB Paru BTA positif dengan variabel sosiodemografi dan variabilitas iklim di Provinsi Jawa Barat tahun 2013-2017. Analisis data dilakukan dengan uji korelasi Spearman, Moran's I, LISA, dan BiLISA. Hasil penelitian ini menunjukkan tidak terdapat autokorelasi spasial Kejadian TB Paru di provinsi Jawab Barat. Hasil analisis bivariat LISA (BiLISA) menunjukkan terdapat autokorelasi spasial lokal pada variable Rumah Sehat di tahun 2013 TB Paru BTA positif dengan pola acak. Tidak terdapat autokorelasi spasial antara factor sosidemografi lainnya dengan Kejadian TB Paru positif. Diharapkan kepada Dinas Kesehatan untuk meningkatkan upaya penemuan kasus dan meningkatkan promosi kesehatan terkait penyakit TB Paru, rumah sehat dan perilaku hidup bersih dan sehat pada daerah-daerah dan masyarakat yang berada di lokasi berisiko.
\end{abstract}

Kata Kunci : Tuberkulosis, Autokorelasi Spasial, Sosiodemografi, Iklim

\begin{abstract}
Tuberculosis is an infectious disease that is the leading cause of death in the world. West Java Province is the province with the highest number of pulmonary TB cases in Indonesia. Among the various factors that influence the incidence of TB is the spatial aspect. This study is an ecological study with the aims to determine the spatial distribution and autocorrelation of smear-positive pulmonary TB events with sociodemographic variables and climate variability in West Java Province in 2013-2017. Data analysis was performed with the Spearman, Moran's I, LISA, and BiLISA correlation tests. The results of this study indicate that there is no spatial autocorrelation of the incidence of pulmonary TB in the province of West Answer. The results of the bivariate analysis of LISA (BiLISA) showed that there was a local spatial autocorrelation on the Healthy House variable in 2013 with positive smear positive pulmonary TB with a random pattern. There is no spatial autocorrelation between other sociodemographic factors and the incidence of positive pulmonary TB. Health Office shouldl increase efforts to find cases and improve health promotion related to pulmonary TB, healthy homes, and clean and healthy living behaviors in areas and communities atrisk locations.
\end{abstract}

Keywords : Pulmonary TB, Spatial Autocorrelation, Sociodemographic, Climate

\section{PENDAHULUAN}

Tuberkulosis merupakan penyakit menular penyebab kematian nomor satu di http://ejournal.urindo.ac.id/index.php/jukmas dunia. Diperkirakan sekitar 10 juta orang di dunia terinfeksi kasus TB baru (5,7 juta laki-laki; 3,2 juta perempuan; 1,1 juta anak-anak), dan menyebabkan 1,5 juta kematian (1). Indonesia

Article History : 
menjadi negara ketiga dengan jumlah kasus TB Paru terbanyak di dunia. Menurut hasil Riskesdas (2018), kasus TB di Indonesia cenderung tinggi dan berkembang pesat pada pada kelompok usia 15 tahun ke atas, orang yang hidup dalam kemiskinan, tingkat pendidikan rendah dan kelompok masyarakat dengan tingkat sosial ekonomi menengah hingga terbawah. Jawa Barat merupakan Provinsi penyumbang jumlah kasus terbanyak di Indonesia, dan sebagian besar terjadi pada kelompok usia 15 tahun ke atas (3).

TB merupakan penyakit sosial, sehingga peningkatan pola kejadian peyakitnya dapat dipengaruhi oleh kondisi lingkungan sekitar melalui adanya interaksi sosial (4). Penyakit TB memiliki kecenderungan menyebabkan pengelompokan spasial karena sebagian besar penderitanya memiliki determinan sosial yang sama dan tinggal berkelompok sehingga memperbesar risiko terinfeksi TB (5). Beberapa studi sebelumnya (6-9) menunjukkan bahwa kejadian penyakit TB cenderung memiliki pengelompokan spasial, pola musiman dan tinggi di daerah-daerah rentan (memiliki jumlah kasus TB BTA positif tinggi, padat penduduk, sosial ekonomi rendah, kondisi lingkungan buruk).

Penggunaan analisis spasial dalam mengkaji kejadian TB Paru berdasarkan tempat dapat memberikan informasi yang lebih detail dan komprehensif. Diantaranya untuk mengetahui kecenderungan letak dan sebaran masalah kesehatan sehingga dapat mendeteksi area dengan risiko TB tinggi. Informasi yang diberikan juga dapat menjelaskan faktor spasial yang berperan dalam kejadian penyakit dan peta endemisitas penyakit yang dapat mempengaruhi luasnya penularan ke wilayah lainnya.

\section{METODE}

Penelitian ini merupakan studi ekologi dengan pendekatan analisis spasial dan berbasis pada data sekunder. Penelitian dilakukan di Provinsi Jawa Barat dengan unit analisis 27 Kabupaten/Kota pada bulan Mei-Juni 2020. Sampel dalam penelitian ini adalah angka penemuan kasus baru (CDR) TB Paru BTA positif di Provinsi Jawa Barat tahun 2013-2017. Data yang digunakan dalam penelitian diperoleh dari dokumen publikasi yang dikeluarkan oleh Dinas Kesehatan Provinsi Jawa Barat (Data CDR TB Paru
BTA Positif, Cakupan Rumah Sehat, Cakupan Ruma ber-PHBS), Badan Pusat Statistik (Data Kepadatan Penduduk dan Kemiskinan), Badan Meteorologi Klimatologi dan Geofisika Provinsi Jawa Barat (Data variabilitas iklim yaitu rata-rata per tahun: suhu udara $\left({ }^{\circ} \mathrm{C}\right)$, kelembaban (\%), curah hujan $(\mathrm{mm})$, dan durasi penyinaran matahari (\%), dan Badan Informasi Geospasial (Peta administrasi Provinsi Jawa Barat).

Analisis data spasial yang dilakukan adalah Global Moran's I dan Local Moran's I (LISA) menggunakan Aplikasi Quantum GIS (QGis) dan Geoda. Sedangkan analisis statistic menggunakan uji korelasi spearman dengan SPSS.

\section{HASIL}

Hasil analisis univariat CDR TB Paru BTA positif dan variabel sosiodemografi (kepadatan penduduk, kemiskinan, cakupan rumah sehat, dan cakupan rumah ber-PHBS) ditampilan dalam Gambar 1.

Berdasarkan data dari Dinas Kesehatan Provinsi Jawa Barat, kecenderungan kasus baru TB Paru BTA positif di setiap Kabupaten/Kota menunjukkan tren yang fluktuatif dengan penemuan kasus tertinggi pada tahun 2016 di Kota Sukabumi dan Kota Banjar (Gambar 1a).

Kepadatan penduduk di setiap Kabupaten/Kota semakin meningkat dari tahun ke tahun terutama di wilayah perkotaan, dan hampir semua wilayah Kota memiliki kepadatan penduduk yang tinggi (Gambar 1b).

Persentase kemiskinan cenderung menurun dengan kemiskinan yang tinggi cenderung berada pada wilayah Kabupaten yang masih memiliki karakteristik pedesaan (Gambar $1 c)$.

Tren cakupan rumah sehat (Gambar $1 d$ ) dan cakupan rumah tangga ber-PHBS (Gambar 1e) menunjukkan cakupan yang semakin meningkat dari tahun ke tahun namun sebagian besar daerah masih memiliki cakupan kurang dari $70 \%$. 


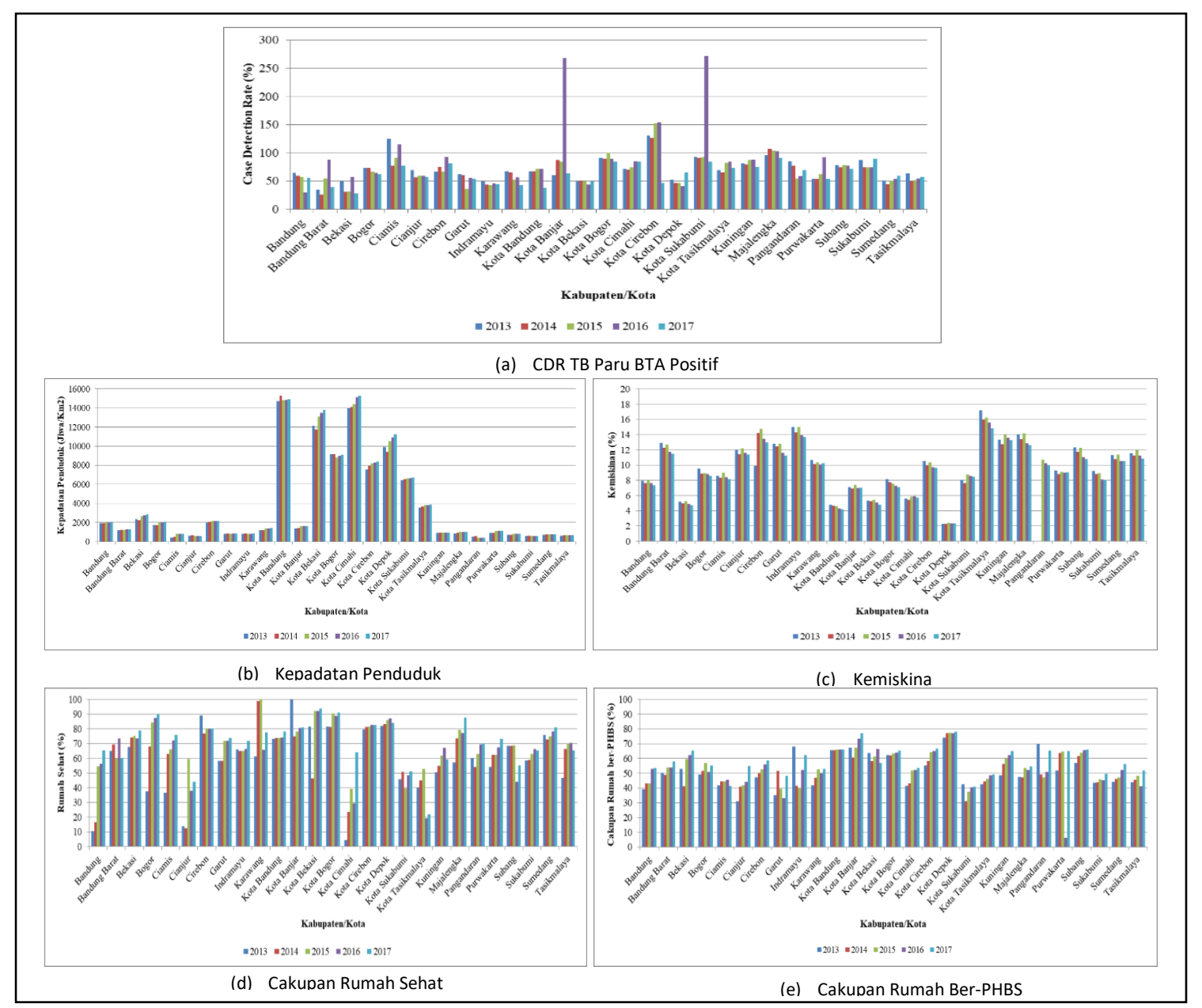

Gambar 1. Tren CDR TB Paru BTA Positif dan Variabel Sosiodemografi di Provinsi Jawa Barat Tahun 2013-2017

Berdasarkan Gambar 2, suhu udara di Provinsi Jawa barat tahun 2013-2017 berkisar antara $23,3^{\circ} \mathrm{C}-25,7^{\circ} \mathrm{C}$ dengan suhu terendah pada tahun 2017 dan suhu tertinggi pada tahun 2016 (Gambar 2a). Kelembaban udara di Provinsi Jawa barat cenderung stabil dan tidak menunjukkan adanya peningkatan atau penurunan yang signifikan dengan kelembaban terendah $74 \%$ (2015) dan kelembaban tertinggi 80\% (2016) (Gambar 2b).

Dalam lima tahun periode yang diamati, curah hujan tertinggi di Provinsi Jawa Barat terjadi pada tahun 2016 dengan curah hujan rata-rata $295,8 \mathrm{~mm}$ dan terendah pada tahun 2015 dengan curah hujan rata-rata $184,7 \mathrm{~mm}$ (Gambar 2c). Lama penyinaran matahari tertinggi di Provinsi Jawa Barat dalam lima tahun adalah pada tahun 2015 yaitu sebesar $67 \%$ dan terendah adalah pada tahun 2016 sebesar 51,58\% (Gambar 2d).

pada tahun 2016 dengan curah hujan rata-rata $295,8 \mathrm{~mm}$ dan terendah pada tahun 2015 dengan curah hujan rata-rata $184,7 \mathrm{~mm}$ (Gambar 2c). Lama penyinaran matahari tertinggi di Provinsi Jawa Barat dalam lima tahun adalah pada tahun 2015 yaitu sebesar $67 \%$ dan terendah adalah pada tahun 2016 sebesar $51,58 \%$ (Gambar 2d). 


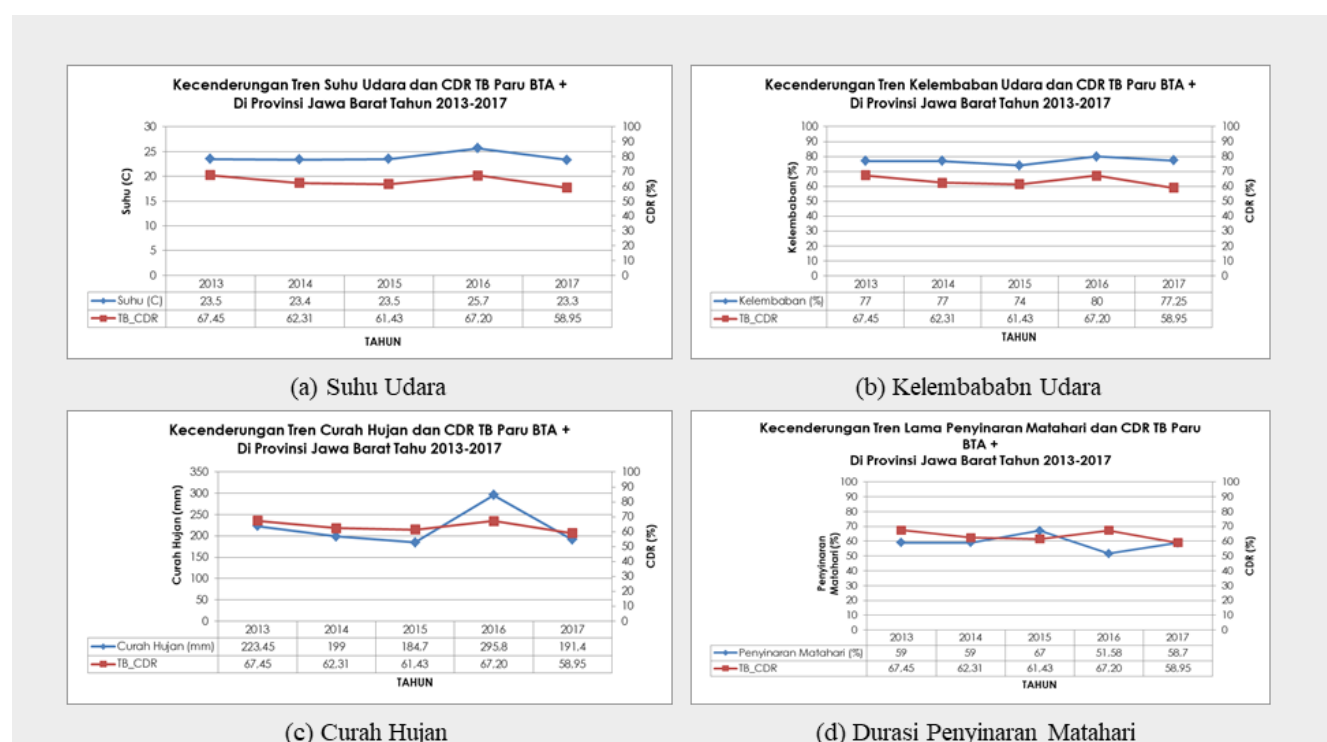

Gambar 2. Tren CDR TB Paru BTA Positif dan Variabilitas Iklim di Provinsi Jawa Barat Tahun 2013-2017

Hasil uji statistik pada Tabel.1 menunjukkan tidak terdapat korelasi yang signifikan antara CDR TB Paru BTA positif dengan kepadatan penduduk, kemiskinan, cakupan rumah sehat, cakupan rumah berPHBS, suhu udara, kelembaban, curah hujan dan durasi penyinaran matahari di Provinsi Jawa Barat tahun 2013-2017 ( $p$-value $>0.05$ ).

Tabel 1. Korelasi antara TB Paru BTA Positif dengan Variabel Sosiodemografi dan Variabilitas Iklim di Provinsi Jawa Barat Tahun 2013-2017

\begin{tabular}{lcc}
\hline \multicolumn{1}{c}{ Variabel } & $\boldsymbol{r}$ & P-value \\
\hline Kepadatan Penduduk & & \\
2013 & -0.145 & 0.470 \\
2014 & 0.178 & 0.374 \\
2015 & 0.218 & 0.275 \\
2016 & 0.312 & 0.113 \\
2017 & 0.092 & 0.650 \\
Kemiskinan & & \\
2013 & 0.130 & 0.526 \\
2014 & -0.078 & 0.706 \\
2015 & -0.024 & 0.906 \\
2016 & -0.069 & 0.732 \\
2017 & -0.167 & 0.406 \\
Cakupan Rumah Sehat & & \\
2013 & -0.239 & 0.230 \\
2014 & -0.137 & 0.494 \\
2015 & -0.050 & 0.804 \\
2016 & -0.068 & 0.735 \\
2017 & -0.025 & 0.901 \\
Cakupan Rumah Tangga ber-PHBS & & \\
2013 & -0.038 & 0.849 \\
2014 & 0.056 & 0.781 \\
2015 & 0.085 & 0.674
\end{tabular}

http://ejournal.urindo.ac.id/index.php/iukmas 


$\begin{array}{lcc}2016 & -0.057 & 0.778 \\ 2017 & -0.240 & 0.228 \\ \text { Variabilitas Iklim } & & \\ \text { Suhu } & 0.580 & 0.306 \\ \text { Kelembaban } & 0.447 & 0.450 \\ \text { Curah Hujan } & 0.800 & 0.104 \\ \text { Durasi Sinar Matahari } & -0.447 & 0.450\end{array}$

Sumber: Hasil pengolahan data Dinas Kesehatan Provinsi Jawa Barat, Badan Pusat Statistik, Badan Meteorologi Klimatologi dan Geofisika

Berdasarkan Uji autokorelasi spasial menunjukkan tidak terdapat autokorelasi spasial

Kejadian TB Paru di Provinsi Jawa Barat (Tabel 2) dan pola spasial secara acak (Gambar 3)

Tabel 2. Hasil Uji Univariat Global Moran's I CDR TB Paru BTA Positif di Provinsi Jawa Barat Tahun 2013-2017

\begin{tabular}{ccccc}
\hline Tahun & Moran's I & $\mathbf{E}(\mathbf{I})$ & Z Score & Keterangan \\
\hline $\mathbf{2 0 1 3}$ & 0.096 & -0.0385 & 0.9462 & Tidak Signifikan \\
$\mathbf{2 0 1 4}$ & 0.153 & -0.0385 & 1.3072 & Tidak Signifikan \\
$\mathbf{2 0 1 5}$ & 0.140 & -0.0385 & 1.2396 & Tidak Signifikan \\
$\mathbf{2 0 1 6}$ & 0.142 & -0.0385 & 1.4730 & Tidak Signifikan \\
$\mathbf{2 0 1 7}$ & 0.160 & -0.0385 & 1.3491 & Tidak Signifikan \\
\hline
\end{tabular}

Sumber : Hasil pengolahan data Dinas Kesehatan Provinsi Jawa Barat

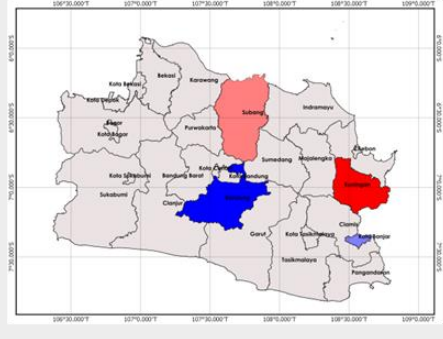

2013

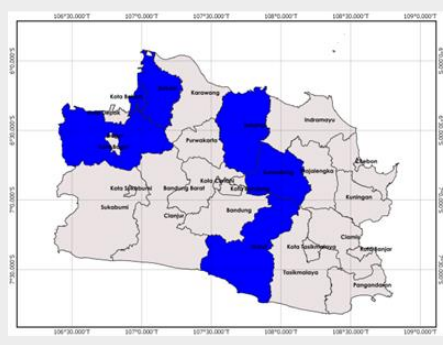

2016

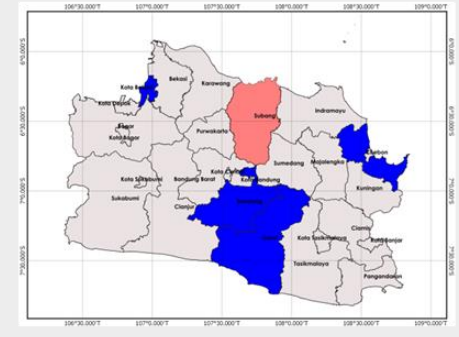

2014

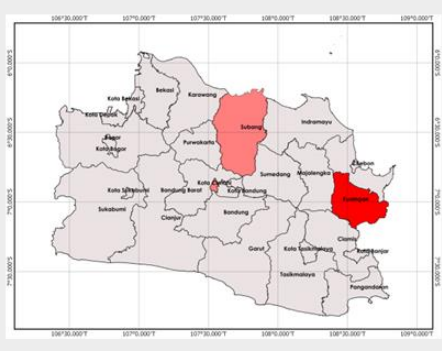

2017

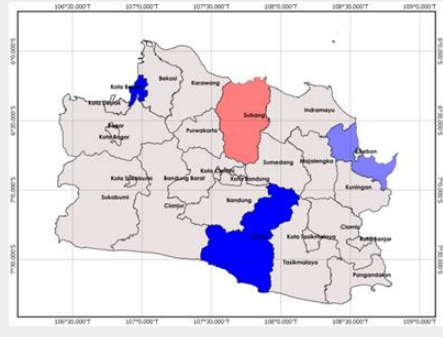

2015

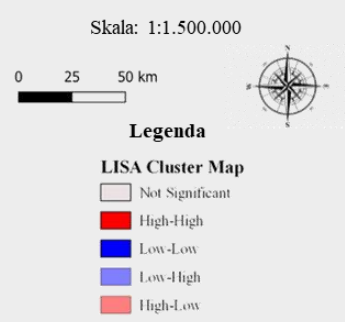

Gambar 3. Peta Pengelompokan Univariat LISA CDR TB Paru BTA Positif di Provinsi Jawa Barat Tahun 2013-2017

Hasil analisis menunjukkan terdapat beberapa daerah yang membentuk autokorelasi spasial lokal yang signifikan di beberapa wilayah setiap tahunnya. Kluster yang terbentuk teridentifikasi pada semua kuadran dan cenderung terjadi di beberapa lokasi yang sama setiap tahunnya. Selama 4 tahun, Kabupaten Subang selalu berada pada kuadran high-low, yaitu daerah yang memiliki jumlah penemuan kasus tinggi dan dikelilingi oleh daerah dengan jumlah penemuan kasus yang rendah. 
Tabel 3. Hasil Uji Bivariat Global Moran's I antara CDR TB Paru BTA Positif dengan Kepadatan Penduduk, Kemiskinan, Cakupan Rumah Sehat, dan Cakupan Rumah Tangga ber-PHBS di Provinsi Jawa Barat Tahun 2013-2017

\begin{tabular}{|c|c|c|c|c|}
\hline Tahun & Moran's I & $E(I)$ & Z Score & Keterangan \\
\hline \multicolumn{5}{|c|}{ Kepadatan Penduduk } \\
\hline 2013 & -0.065 & -0.0385 & -0.4924 & Tidak Signifikan \\
\hline 2014 & -0.063 & -0.0385 & -0.5127 & Tidak Signifikan \\
\hline 2015 & -0.069 & -0.0385 & -0.5194 & Tidak Signifikan \\
\hline 2016 & 0.011 & -0.0385 & 0.3294 & Tidak Signifikan \\
\hline 2017 & -0.036 & -0.0385 & -0.2185 & Tidak Signifikan \\
\hline \multicolumn{5}{|c|}{ Kemiskinan } \\
\hline 2013 & -0.056 & -0.0385 & -0.4507 & Tidak Signifikan \\
\hline 2014 & 0.115 & -0.0385 & 1.0578 & Tidak Signifikan \\
\hline 2015 & 0.131 & -0.0385 & 1.2120 & Tidak Signifikan \\
\hline 2016 & -0.036 & -0.0385 & -0.4396 & Tidak Signifikan \\
\hline 2017 & -0.067 & -0.0385 & -0.6893 & Tidak Signifikan \\
\hline \multicolumn{5}{|c|}{ Cakupan Rumah Sehat } \\
\hline 2013 & 0.222 & -0.0385 & 1.9894 & Signifikan \\
\hline 2014 & 0.142 & -0.0385 & 1.1958 & Tidak Signifikan \\
\hline 2015 & -0.010 & -0.0385 & -0.1158 & Tidak Signifikan \\
\hline 2016 & -0.117 & -0.0385 & -1.1910 & Tidak Signifikan \\
\hline 2017 & -0.029 & -0.0385 & -0.3181 & Tidak Signifikan \\
\hline \multicolumn{5}{|c|}{ Cakupan Rumah Tangga ber-PHBS } \\
\hline 2013 & 0.002 & -0.0385 & 0.0895 & Tidak Signifikan \\
\hline 2014 & -0.017 & -0.0385 & -0.1571 & Tidak Signifikan \\
\hline 2015 & 0.019 & -0.0385 & 0.2227 & Tidak Signifikan \\
\hline 2016 & 0.006 & -0.0385 & 0.1067 & Tidak Signifikan \\
\hline 2017 & -0.076 & -0.0385 & -0.7708 & Tidak Signifikan \\
\hline
\end{tabular}

Hasil analisis menunjukkan hanya variabel rumah sehat tahun 2013 yang memiliki autokorelasi dengan kejadian CDR TB Paru di Provinsi Jawa Barat. Analisis lanjutan dengan bivariat LISA pada Gambar 4, menunjukkan pada tahun 2013 terdapat empat daerah dengan autokorelasi spasial lokal yang signifikan yang membentuk pola mengelompok. Sedangkan pada tahuntahun selanjutnya tidak terdeteksi adanya pola spasial global namun terdapat autokorelasi spasial lokal yang signifikan di beberapa wilayah lainnya pada semua kuadran. namun hanya variabel cakupan rumah sehat karena memiliki autokorelasi spasial yang signifikan baik secara global maupun lokal. 


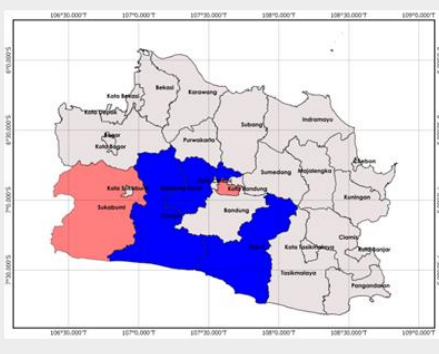

2013

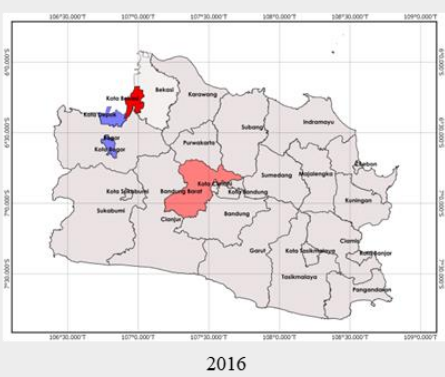

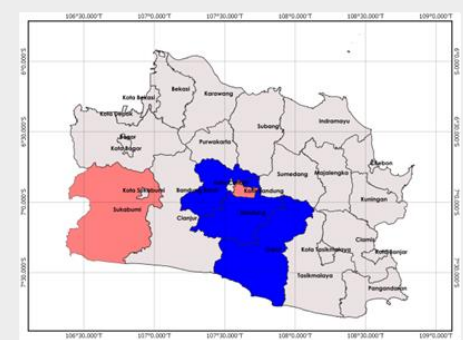

2014

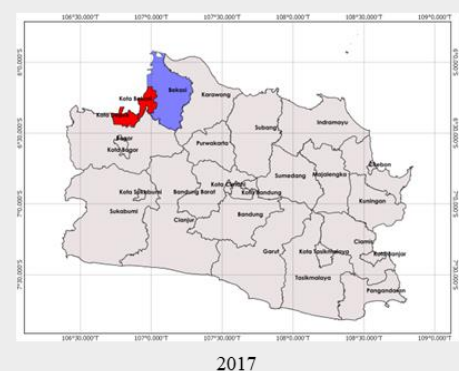

2017

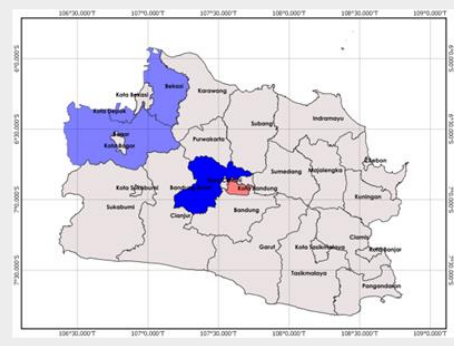

2015

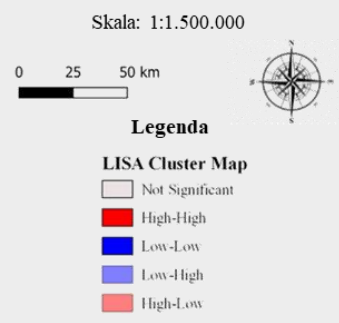

Gambar 4. Peta Pengelompokan Bivariat LISA antara CDR TB Paru BTA Positif dengan Cakupan Rumah Sehat di Provinsi Jawa Barat Tahun 2013-2017

Pada Gambar 4. menunjukkan pada tahun 2013 terdapat empat daerah dengan autokorelasi spasial lokal yang signifikan yang membentuk pola mengelompok, hal ini sesuai dengan hasil uji Global Moran's I yang mendeteksi adanya pola spasial yang signifikan. Sedangkan pada tahun-tahun selanjutnya tidak terdeteksi adanya pola spasial global namun terdapat autokorelasi spasial lokal yang signifikan di beberapa wilayah lainnya pada semua kuadran. Hasil uji bivariat LISA pada variabel lainnya menunjukkan terdapat autokorelasi spasial lokal yang signifikan di beberapa wilayah.

\section{PEMBAHASAN}

Angka penemuan kasus baru TB Paru BTA positif di Jawa Barat cenderung menurun dari tahun ke tahun dengan distribusi CDR yang masih rendah di sebagian besar wilayah. Penelitian ini menunjukkan tidak terdapat pola spasial TB yang signifikan setiap tahunnya, namun menunjukkan terdapat beberapa daerah yang membentuk kluster spasial lokal yang signifikan menurut LISA. Hasil penelitian ini sama dengan penelitian sebelumnya $(8,10)$, namun tidak sama dengan penelitian Lima et al. (2019) (7). Perbedaan hasil ini kemungkinan dipengaruhi oleh adanya perbedaan kondisi geografis di setiap daerah serta unit analisis yang diteliti. Meskipun tidak terdapat pola spasial yang mengelompok, teridentifikasinya kluster spasial lokal menunjukkan adanya perbedaan distribusi kasus di setiap wilayah (10).

Perbedaan angka penemuan kasus di setiap wilayah dipengaruhi oleh beberapa kondisi seperti kondisi geografis masing-masing wilayah, faktor sosiodemografi, peran petugas program dalam upaya penemuan kasus, preferensi berobat pasien serta kemudahan akses ke pelayanan kesehatan $(6,11)$. Pasien dengan TB BTA positif lebih infeksius, sehingga kasus TB Paru BTA positif menjadi salah satu indikator risiko penularan TB (12). Oleh karena itu, daerah yang memilliki dan dikelilingi oleh daerah dengan penemuan kasus tinggi harus menjadi perhatian dalam upaya penanggulangan TB. Daerah dengan penemuan kasus rendah dan dikelilingi oleh daerah dengan penemuan kasus tinggi atau sebaliknya kemungkinan merupakan daerah yang menerima limpahan kasus dari daerah tetangganya karena banyak pasien yang berobat ke luar daerah sehingga pencatatan dan laporan kasusnya terdata di tempat pengobatan, contohnya adalah banyak penduduk Kabupaten Indramayu yang berobat ke pelayanan kesehatan di Kota Cirebon, sehingga penemuan kasus di Kab. Indramayu rendah dan di Kota Cirebon tinggi (11).

Sebaran kepadatan penduduk di Provinsi Jawa Barat menunjukkan distribusi yang tidak merata dengan kesenjangan yang sangat luas. 
Dalam penelitian ini tidak ditemukan adanya hubungan yang signifikan antara kepadatan penduduk dengan TB Paru BTA positif $(p>0.05)$. Hasil penelitian ini memiliki temuan yang sama dengan beberapa penelitian sebelumnya $(13,14)$, namun berbeda dengan hasil dua penelitian lainnya $(15,16)$ yang menunjukkan adanya hubungan yang signifikan. Penelitian ini juga menunjukkan tidak terdapat pengelompokan spasial global yang signifikan antara kepadatan penduduk dengan CDR TB Paru BTA Positif, namun terdapat autokorelasi spasial lokal yang signifikan di beberapa daerah pada semua kluster, sejalan dengan penelitian sebelumnya yang dilakukan Soo (2014).

Kondisi yang padat dapat meningkatkan risiko peningkatan paparan terhadap orang yang menderita TB Paru sehingga akan memudahkan penyebaran kuman $(14,17)$ Terlepas dari kondisi kepadatan penduduk, kejadian TB juga dipengaruhi oleh faktor risiko lain seperti kemiskinan tinggi, cakupan rumah sehat rendah dan PHBS rendah. Sehingga tingginya penemuan kasus TB di suatu daerah kemungkinan dipengaruhi karakteristik variabel lainnya (12).

Tidak ditemukan adanya hubungan yang signifikan antara kemiskinan dengan TB Paru BTA positif $(p>0.05)$. Hasil temuan dalam penelitian ini sesuai dengan temuan pada beberapa penelitian sebelumnya $(13,15)$, namun berbeda dengan hasil penelitian Harling and Castro (2014) yang menemukan adanya hubungan yang signifikan (17). Penelitian ini juga menunjukkan tidak terdapat pengelompokan spasial global yang signifikan antara kemiskinan dengan TB Paru BTA Positif, namun terdapat autokorelasi spasial lokal yang signifikan di beberapa daerah pada semua kluster, sejalan dengan penelitian sebelumnya (8).

Masyarakat dengan kondisi miskin mempunyai keterbatasan dalam mengakses pelayanan kesehatan dan perumahan sehat (18), kemiskinan juga menyebabkan rendahnya kemampuan untuk mengonsumsi makanan yang bergizi (17) sehingga meningkatkan kerentanan terhadap penularan TB. Tidak ditemukannya hubungan dan autokorelasi spasial yang signifikan dalam penelitian ini bisa jadi karena faktor lain seperti perpindahan penduduk dan terbatasnya sumber daya dan pelayanan kesehatan, sehingga darah dengan kondisi sosial ekonomi yang baik tetap memiliki risiko penularan yang tinggi (19).

Tidak ditemukan adanya hubungan yang signifikan antara cakupan rumah sehat dengan TB Paru BTA positif $(p>0.05)$. Hasil temuan dalam penelitian ini sejalan dengan beberapa penelitian sebelumnya $(14,20)$, namun tidak sesuai dengan penelitian Saputra (2020) yang menunjukkan hasil signifikan. Penelitian ini mengidentifikasi adanya autokorelasi spasial global yang signifikan antara CDR dengan cakupan rumah sehat pada tahun 2013 di wilayah Barat Daya, artinya hubungan spasial antara CDR dengan cakupan rumah sehat memiliki pola yang mengelompok. Sedangkan pada tahun-tahun selanjutnya (2014-2017) tidak terdapat pengelompokan spasial yang signifikan.

Kondisi rumah yang tidak sehat akan menjadi reservoir bagi seluruh lingkungan. Sehingga semakin baik cakupan rumah sehat di suatu wilayah akan semakin memperkecil risiko masyarakat menjadi sakit (3). Keberadaan kuman TB atau penderita TB Paru BTA positif di dalam rumah dengan kondisi yang tidak memadai akan meningkatkan jumah kontak dengan kuman atau penderita sehingga menyebabkan terjadinya infeksi. Sedangkan kondisi rumah yang memenuhi syarat sehat akan mengurangi potensi perkembangan kuman penyebab penyakit dan terjadinya penularan penyakit (21).

Tidak tidak ditemukan adanya hubungan yang signifikan antara cakupan rumah tangga ber-PHBS dengan TB Paru BTA positif $(p>0.05)$. Temuan ini sesuai dengan penelitian sebelumnya (22) dimana beberapa aspek PHBS tidak memiliki hubungan yang signfikan dengan kejadian TB, namun tidak sesuai dengan penelitian Kurniawan (2010) dan Saputra et al., (2020). Penelitian ini juga menunjukkan tidak terdapat pengelompokan spasial global yang signifikan antara cakupan rumah ber-PHBS dengan CDR TB Paru BTA Positif, namun terdapat beberapa daerah yang memiliki autokorelasi spasial lokal yang signifikan.

Perilaku seorang penderita TB mengenai cara batuk dan membuang dahak yang tidak sesuai etika menjadi salah satu faktor risiko penularan TB ke orang lain (24). Perilaku merokok dan kebiasaan mengonsumsi makanan juga merupakan salah satu aspek PHBS yang 
kaitannya dengan status gizi atau imunitas yang dapat memengaruhi kondisi kesehatan. Orang dengan imunitas yang buruk akan rentan untuk sakit jika terinfeksi kuman TB $(1,24)$.

Tiga unsur variabilitas iklim di Provinsi Jawa Barat yaitu suhu, kelembaban dan curah hujan menunjukkan tren yang konsisten dengan penurunan dan peningkatan kasus TB Paru BTA positif. Sedangkan durasi paparan sinar matahari menunjukkan tren yang berkebalikan dengan penurunan dan peningkatan kasus TB. Meskipun menunjukkan kekuatan hubungan yang cukup kuat, hasil statistik menunjukkan tidak terdapat hubungan yang signifikan antara variabilitas iklim dengan TB Paru, sejalan dengan penelitian sebelumnya (13). Hasil yang tidak signifikan kemungkinan terjadi karena durasi penelitian yang sangat singkat.

Kondisi Iklim merupakan salah satu faktor yang dapat berpengaruh terhadap perkembangan mikroorganisme penyebab penyakit (25). Perubahan iklim akan diikuti oleh perubahan ekosistem yang dapat merubah pola interaksi antara lingkungan dan manusia yang berdampak terhadap kesehatan. Beberapa penelitian menunjukkan pola musiman TB yang meningkat pada musim semi dan musim panas $(26,27)$. Ketika musim dingin, tingkat paparan sinar matahari akan semakin rendah (27) dan biasanya akan semakin banyak aktifitas dalam ruangan yang menyebabkan kondisi lingkungan menjadi padat, lembab, dan sirkulasi udaran menurun, akan meningkatkan viabilitas kuman TB (26). Selain viabilitas $M$. tb, Perubahan iklim juga akan berpengaruh terhadap sistem imun individu. Kurangnya paparan sinar matahari akan berdampak pada penurunan kadar vitamin $D$ (28). Keberadaan kuman TB di lingkungan yang kontak dengan seseorang pada kondisi imun kurang baik, akan memudahkan perkembangan dan memperparah kondisi penyakit. Seseorang yang mengalami kontak pada saat musim dingin dan mengembangkan infeksi kemungkinan akan menjadi kasus pada musim panas.

\section{KESIMPULAN}

Tidak terdapat korelasi yang signifikan antara kejadian TB Paru BTA Positif dengan variabel sosiodemografi (kepadatan penduduk, kemiskinan, cakupan rumah sehat, cakupan rumah tangga ber-PHBS) dan variabilitas iklim (suhu udara, kelembaban, curah hujan dan durasi penyinaran matahari) di Provinsi Jawa Barat tahun 2013-2017. Tidak terdapat autokorelasi spasial global yang signifikan pada kejadian TB Paru BTA positif dan variabel sosiodemografi, kecuali variabel cakupan rumah sehat pada tahun 2013, namun terdapat autokorelasi spasial lokal yang signifikan di beberapa wilayah pada semua variabel setiap tahunnya.

Oleh karena itu, disarankan bagi Dinas Kesehatan Provinsi Jawa Barat untuk memperbaiki kualitas data yang dipublikasikan terutama terkait data kasus dengan memisahkan kasus yang berasal dari dalam dan luar daerah. Dinas Kesehatan juga sebaiknya meningkatkan upaya pencegahan dan pengendalian yang merata di semua wilayah Kabupaten/Kota karena sebaran penyakit TB terjadi secara acak dan tidak membentuk pola spasial sehingga setiap wilayah memiliki potensi yang sama terhadap penyebaran penyakit TB. Diharapkan untuk penelitia selanjutnya agar dapat melakukan penelitian dengan unit analisis yang lebih kecil seperti Desa atau Kecamatan serta memastikan validitas data yang digunakan agar hasil penelitian lebih valid.

\section{UCAPAN TERIMA KASIH}

Ucapan terima kasih dapat diberikan kepada: Dinas Kesehatan Provinsi Jawa Barat, Badan Pusat Statistik, Badan Meteorologi Klimatologi dan Geofisika, dan Badan Informasi Geospasial yang telah menyediakan data yang diperlukan dalam penelitian ini.

\section{DAFTAR PUSTAKA}

1. WHO. Global Tuberculosis Report 2019. Geneva; 2019. 297 p.

2. RISKESDAS. Hasil Utama Riset Kesehatan Dasar 2018. Kementrian Kesehat Republik Indones. 2018;1(1):1-200.

3. Dinkes Provinsi Jawa Barat. Profil Kesehatan Provinsi Jawa Barat 2017. 2018. 52 p.

4. Oren E, Koepsell T, Leroux BG, Mayer J. Area-based socio-economic disadvantage and tuberculosis incidence. Int J Tuberc Lung Dis. 2012;16(7):880-5.

5. Wardani DWSR, Lazuardi L, Mahendradhata 
$\mathrm{Y}$, Kusnanto H. Pentingnya Analisis Cluster Berbasis Spasial dalam Penanggulangan Tuberkulosis di Indonesia. Kesmas Natl Public Heal J. 2013;(1):147.

6. Dangisso $\mathrm{MH}$, Datiko DG, Lindtjørn B. Spatio-temporal analysis of smear-positive tuberculosis in the Sidama Zone, Southern Ethiopia. PLoS One. 2015;10(6):1-19.

7. Lima SVMA, Dos Santos AD, Duque AM, De Oliveira Goes MA, Da Silva Peixoto MV, Da Conceição Araújo $D$, et al. Spatial and temporal analysis of tuberculosis in an area of social inequality in Northeast Brazil. BMC Public Health. 2019;19(1):1-9.

8. Soo BY. A Spatial Analysis of Tuberculosis and its Relationship to Social Characteristics in Korea. 2014.

9. Li XX, Wang LX, Zhang J, Liu YX, Zhang H, Jiang SW, et al. Exploration of ecological factors related to the spatial heterogeneity of tuberculosis prevalence in P. R. China. Glob Health Action. 2014;7(1).

10. Álvarez-Hernández G, Lara-Valencia $F$, Reyes-Castro PA, Rascón-Pacheco RA. An analysis of spatial and socio-economic determinants of tuberculosis in Hermosillo, Mexico, 2000-2006. Int J Tuberc Lung Dis. 2010;14(6):708-13.

11. Dinkes Jawa Barat. LKIP 2016 (Laporan Kinerja Instansi Pemerintah). Dinas Kesehatan Provinsi Jawa Barat. 2017.

12. Zhao F, Cheng $S$, He G, Huang $F$, Zhang $H, X u$ $B$, et al. Space-Time Clustering Characteristics of Tuberculosis in. PLoS One. 2013;8(12):2005-11.

13. Achmad FA. Analisis Spasial Penyakit Tuberkulosis Paru BTA Positif di Kota Administrasi Jakarta Selatan Tahun 20072009. 2010.

14. Haq A, Achmadi UF, Susanna D. Analisis Spasial (Topografi) Tuberkulosis Paru Di Kota Pariaman, Bukittinggi, Dan Dumai Tahun 2010-2016. J Ekol Kesehat. 2019;18(3):149-58.

15. De Abreu E Silva M, Di Lorenzo Oliveira $C$, Teixeira Neto RG, Camargos PA. Spatial distribution of tuberculosis from 2002 to
2012 in a midsize city in Brazil. BMC Public Health [Internet]. 2016;16(1):1-8. Available from: http://dx.doi.org/10.1186/s12889016-3575-y

16. Mahara G, Yang K, Chen S, Wang W, Guo X. Socio-Economic Predictors and Distribution of Tuberculosis Incidence in Beijing, China: A Study Using a Combination of Spatial Statistics and GIS Technology. Med Sci. 2018;6(2):26.

17. Harling G, Castro MC. A spatial analysis of social and economic determinants of tuberculosis in Brazil. Heal Place. 2014;

18. Ruswanto B. Analisis Spasial Sebaran Kasus Tuberkulosis Paru Ditinjau Dari Faktor Lingkungan Dalam dan Luar Rumah di Kabupaten Pekalongan. Universitas Diponegoro. 2010.

19. Ge E, Zhang X, Wang X, Wei X. Spatial and temporal analysis of tuberculosis in Zhejiang Province , China , 2009-2012. Infect Dis Poverty [Internet]. 2016;1-10. Available from: http://dx.doi.org/10.1186/s40249016-0104-2

20. Sasmita, Junaidi H, Ainurafiq. Pola Spasial Kejadian TB Paru BTA Positif di Wilayah Kerja Puskesmas Puuwatu Tahun 20132015. J Ilm Mhs Kesehat Masy [Internet]. 2017;2(6):1-10. Available from: http://ojs.uho.ac.id/index.php/JIMKESMAS/ article/download/3033/2281

21. Saputra FF, Wahjuni CU, Isfandiari MA. Spatial Modeling of Environmental-Based Risk Factors of Tuberculosis in Bali Province: an Ecological Study. J Berk Epidemiol. 2020;8(1):26.

22. Zhafirah N, Susanna D. Perilaku Hidup Bersih dan Sehat ( PHBS ) dengan Kejadian Gangguan Pernapasan pada Balita di Kawasan Pesisir Desa Sedari, Kecamatan Cibuaya , Karawang , Jawa Barat Tahun 2018. J Nas Kesehat Lingkung Glob. 2020;1(1):46-54.

23. Kurniawan DA. Hubungan PHBS dengan Kejadian Tuberkulosis Paru pada Warga di Kelurahan Jaraksari, Wonosobo, Jawa Tengah. 2010.

24. Kemenkes RI. Peraturan Menteri Kesehatan 
Republik Indonesia Nomor 67 Tahun 2016 Tentang Penanggulangan Tuberkulosis. 2016 p. 163.

25. Ortíz Bultó PL, Rodríguez AP, Valencia $A R$, Vega NL, Gonzalez MD, Carrera AP. Assessment of human health vulnerability to climate variability and change in Cuba. Environ Health Perspect. 2006;114(12):1942-9.

26. Fares A. Seasonality of tuberculosis. J Glob Infect Dis. 2011;3(1):46-55.

27. Koh GCKW, Hawthorne G, Turner AM, Kunst
H, Dedicoat M. Tuberculosis Incidence Correlates with Sunshine: An Ecological 28Year Time Series Study. PLoS One. 2013;8(3):1-5.

28. Cui Z, Lin D, Chongsuvivatwong V, Zhao J, Lin $\mathrm{M}, \mathrm{Ou} \mathrm{J}$, et al. Detecting spatiotemporal pattern of tuberculosis and the relationship between ecological environment and tuberculosis, a spatial panel data analysis in Guangxi, China. 2018;1-15. Available from: http://dx.doi.org/10.1101/348169 